\title{
Legume Intercropping to Reduce Erosion, Increase Soil Fertility and Grain Yield, and Stop Burning in Highland Maize Production in Northern Thailand
}

\author{
Adirek Punyalue ${ }^{1}$, Jedsada Jongjaidee ${ }^{1}$, \\ Sansanee Jamjod ${ }^{2}$, and Benjavan Rerkasem ${ }^{3 *}$ \\ ${ }^{1}$ Highland Research and Development Institute, 65 Suthep Road, Chiang Mai 50200, Thailand \\ ${ }^{2}$ Department of Plant and Soil Science, Faculty of Agriculture, Chiang Mai University, \\ Chiang Mai 50200, Thailand \\ ${ }^{3}$ Plant Genetic Resource and Nutrition Laboratory, Chiang Mai University, Chiang Mai \\ 50200, Thailand \\ *Corresponding author.E-mail: benjavan.r@cmu.ac.th \\ https://doi.org/10.12982/CMUJNS.2018.0019
}

Received: March 14, 2018

Revised: May 5,2018

Accepted: May 30, 2018

\begin{abstract}
Residue burning in highland maize production is detrimental to soil fertility and contributes to Southeast Asia's haze problem. This study first determined residue production of four common grain legumes - lablab, rice bean, cowpea and mung beanwhen intercropped with maize at Pang Da Royal Project Station in Chiang Mai, Thailand; the maize-lablab intercrop produced the largest amount of residue with the highest concentration of nitrogen. Then, this intercrop was evaluated for its effect on soil erosion compared to the farmers' practice of growing maize with residue burning, as well as maize without residue burning, on 33-48\% slopes in Santisuk district, Nan province, northern Thailand, in the wet season of 2014 and 2015. Growing maize without burning significantly reduced soil and nitrogen loss in the first year, and with the maize/lablab intercrop reduced them considerably more by the second crop year, to only $11 \%$ of the soil and $14 \%$ of the nitrogen lost under the farmers' practice of burning the maize residue. The effects of intercropping with lablab and not burning were associated with $64 \%$ more residue after two crop years and 24\% higher maize grain yield by the second crop year compared to growing maize alone with residue burning - the farmers' practice. Intercropping highland maize with a legume such as lablab without residue burning effectively reduced soil erosion and increased soil fertility and maize grain yield, while offering the additional benefit of not contributing to the region's haze problem.
\end{abstract}

Keywords: Residue burning, Erosion, Intercrop, Lablab, Maize, Nitrogen 


\section{INTRODUCTION}

The expansion of maize production into the mountainous areas of Southeast Asia that covers Thailand, Lao PDR, and Myanmar (Boundeth et al., 2012; Kitchaicharoen et al., 2015; Woods, 2015) has many undesirable environmental effects. Highland maize is grown by sowing the seed into fields cleared by burning crop residue from the previous season. Burning destroys organic matter, removes the nutrients nitrogen and sulfur, which volatilize in the fire, and deprives the soil surface of protection against the elements. Since most of the highland maize crop is grown on steep slopes, the removal of the crop residue by burning exposes the soil to erosion by water (Hurni, 1982; Hill and Peart, 1998). Residue burning in the highlands also contributes to haze in the dry season, a problem in Southeast Asia. In the highland provinces of Chiang Rai, Chiang Mai, and Nan in northern Thailand, a center of slash-and-burn maize production in the mountainous region of mainland Southeast Asia, peak concentrations of atmospheric particulate matter of $10 \mu \mathrm{m}$ in diameter or less $\left(\mathrm{PM}_{10}\right)$ have been recorded at more than four times the safe standard of $120 \mu \mathrm{g} / \mathrm{m}^{3}$ during the burning season (Pollution Control Department, 2012).

Intercropping is a traditional practice, still common in many parts of the world, of growing more than one species of crop on the same land at the same time (Brooker et al., 2015). Maize/legume intercropping, one of the most common, has been shown to utilize resources efficiently (Okigbo and Greenland, 1976; Beets, 1982; Francis, 1986; Ofori and Stern, 1987). When well nodulated with appropriate nitrogen-fixing bacteria, legumes are independent of soil and fertilizer nitrogen. Cowpea (Vigna unguiculata), mung bean ( . radiata), rice bean (V. umbellata), and lablab (Lablab purpureus) are among grain legumes commonly grown in the highlands of Thailand (Rerkasem and Rerkasem, 1987; Yimyam, 2006; Chaiwong, 2013). Most local varieties with indeterminate growth habit continue to produce new shoots and leaves and accumulate more biomass after flowering; and have been shown to produce large amounts of biomass (Rerkasem and Rerkasem, 1988; Devkota and Rerkasem, 2000, Chaiwong et al., 2012). This study evaluated the potential of maize/legume intercrop to reduce soil erosion and eliminate burning in highland maize production in northern Thailand.

\section{MATERIALS AND METHODS}

The study involved two experiments. Experiment 1 (Exp. 1) evaluated residue production of lablab, rice bean, cowpea, and mung bean, and their impact on maize yield when intercropped with maize at Pang Da Royal Project Station in Chiang Mai, Thailand $\left(18.86^{\circ} \mathrm{N}\right.$, $98.76^{\circ} \mathrm{E}, 700 \mathrm{~m}$ above sea level), in a field with an $8 \%$ slope. The five cropping systems - the four maize/legume intercrops (without residue burning) and the farmers' practice of growing maize as a monocrop on fields after residue burning - were grown in $5 \times 6 \mathrm{~m}$ plots separated by a $0.5 \mathrm{~m}$ wide space in a randomized complete block trial with three replicated blocks. The seed of maize hybrid CP888, commonly used in the highlands, was sown in May at $0.50 \times 0.75 \mathrm{~m}$ spacing with two plants/hill. Basal nitrogen fertilizer of $72 \mathrm{~kg} \mathrm{~N} / \mathrm{ha}$ (as urea) was applied one month after sowing, followed by $25 \mathrm{~kg} \mathrm{~N}$ and $14 \mathrm{~kg} / \mathrm{ha}$ of phosphorus (P) (as ammonium phosphate) one month later. In the intercropped plots, the seeds of locally 
available legumes were sown between the maize rows at the rate of $50 \mathrm{~kg} / \mathrm{ha}$, one month before the maize harvest, and grown without additional fertilizer. The experiment took place during the wet season over three growing seasons from 2012 to 2014. Grain yield at 14\% moisture and residue dry weight were recorded for both the maize $\left(2.25 \mathrm{~m}^{2}\right.$ area/sample $)$ and legumes $\left(1 \mathrm{~m}^{2}\right.$ area/sample) at maturity. Residue $\mathrm{N}$ concentration for the cropping systems were derived from the maize and legume residue in 2014 that were separately ground and analyzed for Kjeldahl N.

Experiment 2 (Exp. 2) evaluated the effect of maize/lablab intercrop (determined in Exp. 1 as the cropping system that produced the largest amount of residue with the highest $\mathrm{N}$ concentration) in farmers' fields at Na Lou village, Santisuk district, Nan province, Thailand $\left(18.89^{\circ} \mathrm{N}, 100.97^{\circ} \mathrm{E}, 321 \mathrm{~m}\right.$ above sea level) during the wet season of 2014 and 2015. Maize/ lablab was compared with the farmers' practice of growing maize as a monocrop after residue burning, as well as maize as a monocrop grown without residue burning. Each of the three cropping systems were grown in $4 \times 10 \mathrm{~m}^{2}$ erosion plots (Wilson et al., 2008), arranged in completely randomized block in fields on $33 \%, 41 \%$, and $48 \%$ slopes for each of the three replicated blocks. The erosion plots were bounded by $0.30 \mathrm{~m}$ strips of galvanized iron sheet, with a 200-liter sediment trap ( $0.54 \mathrm{~m}$ diameter, $0.88 \mathrm{~m}$ deep) at the bottom of each plot. Basal fertilizer applied included $58 \mathrm{~kg} \mathrm{~N} / \mathrm{ha}$ (as urea) at sowing and ammonium phosphate, which added $20 \mathrm{~kg} \mathrm{~N}$ plus $11 \mathrm{~kg} \mathrm{P}$ ha/ha 60 days later. The CP888 maize hybrid was sown in the same way as in Experiment 1 under three conditions: after residue burning following farmers' practice and with no burning of either the intercrop or maize as a monocrop. The maize seed was sown into the ash-covered soil from the residue burning in the farmers' slash-and-burn treatment, and into the stubble without tillage in the maize monocrop with no prior residue burning. In the maize/lablab treatment, the seed of a local lablab variety (called Paeyee or Pae Lor, local name for grain type Lablab purpureus, to distinguish from the vegetable type called Tua Paeb), was sown between the maize rows at the rate of $50 \mathrm{~kg} / \mathrm{ha}$ one month before the maize harvest, and grown without additional fertilizer. During the growing season rainfall and the volume of water plus sediment in the sediment traps were recorded daily. Samples of the sediment loaded water in the trap were taken for determination of soil and total nitrogen loss. Grain yield and residue dry weight of the maize and lablab were determined as in Exp. 1.

Statistical analysis of data was conducted with Statistix 8 (SXW), with analysis of variance and mean separation with least significant difference (LSD) at $P<0.05$.

\section{RESULTS}

\section{Exp. 1 - Production of residue and accumulation of nitrogen, and the effect on maize yield by four legumes intercropped with maize.}

The four legumes in this study differed markedly in the length of their growing season, with mung bean reaching maturity in 75 days, cowpea in 100 days, rice bean in 120 days, and lablab in 180 days from sowing. Examination of the roots at flowering found all legumes to be well nodulated with healthy pink nodules. Intercropping maize with the legumes significantly increased the maize grain yield, with the different legume intercrops differentially affecting the amount of residue and its $\mathrm{N}$ content (Table 1). 
Table 1. Grain yield, residue dry weight, and nitrogen concentration of the residue from four maize/legume intercrops compared to farmers' practice of residue burning of maize monocrop (Exp. 1)

\begin{tabular}{lcccccc}
\hline & \multicolumn{2}{c}{$\begin{array}{c}\text { Grain yield }^{1} \\
\text { (t/ha) }\end{array}$} & \multicolumn{2}{c}{$\begin{array}{c}\text { Residue dry weight } \\
\text { (t/ha) }\end{array}$} & \multicolumn{2}{c}{$\begin{array}{c}\text { Cropping system } \\
\text { residue nitrogen }\end{array}$} \\
\cline { 2 - 7 } & Maize & Legume & Maize & Legume & kg N/ha & \% N \\
\hline Farmers' practice & $4.17 \mathrm{a}$ & & $3.18 \mathrm{a}$ & & $20.4 \mathrm{a}$ & $0.69 \mathrm{a}$ \\
Maize/lablab & $6.34 \mathrm{c}$ & 0.52 & $4.60 \mathrm{c}$ & $3.94 \mathrm{c}$ & $131.7 \mathrm{c}$ & $1.51 \mathrm{~b}$ \\
Maize/rice bean & $5.89 \mathrm{bc}$ & 0.48 & $4.36 \mathrm{c}$ & $2.41 \mathrm{~b}$ & $72.5 \mathrm{~b}$ & $1.19 \mathrm{ab}$ \\
Maize/cowpea & $5.56 \mathrm{~b}$ & 0.60 & $3.61 \mathrm{~b}$ & $1.27 \mathrm{a}$ & $62.5 \mathrm{ab}$ & $1.18 \mathrm{ab}$ \\
Maize/mung bean & $5.46 \mathrm{~b}$ & 0.43 & $4.23 \mathrm{c}$ & $1.13 \mathrm{a}$ & $62.5 \mathrm{ab}$ & $1.05 \mathrm{ab}$ \\
\hline
\end{tabular}

Significant effects of cropping system by analysis of variance

\begin{tabular}{rrrrrr}
$P<0.01$ & $\mathrm{NS}_{0.05}$ & $P<0.001$ & $P<0.001$ & $P<0.001$ & $P<0.05$ \\
\hline
\end{tabular}

Note: ${ }^{1}$ Means from 2012, 2013, 2014;

${ }^{2}$ From 2014, significant difference by $\mathrm{LSD}_{0.05}$ within same column indicated by different letters.

Maize grain yield averaged over the three crop years was higher in the intercrops than in farmers' practice with residue burning, with the highest yield from maize/lablab. The intercrops produced legume grain yields of $0.43-0.60 \mathrm{t} / \mathrm{ha} / \mathrm{yr}$. Among the legumes, the largest amount of residue was produced by lablab with $3.94 \mathrm{t} / \mathrm{ha}$, followed by rice bean with $2.41 \mathrm{t} / \mathrm{ha}$, cowpea with $1.27 \mathrm{t} / \mathrm{ha}$, and mung bean with $1.13 \mathrm{t} / \mathrm{ha}$. All of the intercrops left more residue behind after the grain harvest than the farmers' practice - by $169 \%$ in maize/lablab, $113 \%$ in maize/rice bean, $69 \%$ in maize/mung bean, and 54\% more in maize/cowpea. In addition to producing more crop residue, the maize/lablab residue contained twice the nitrogen of the other three cropping systems. In the farmers' practice, the small amount of residue that remained from the maize monocrop was lost to burning before sowing the next season's maize.

\section{Exp. 2 - Effects of maize/lablab intercrop on soil and nitrogen loss by erosion.}

Rainfall from June to November at the site of Exp. 2 was $819 \mathrm{~mm}$ in 2014 and $888 \mathrm{~mm}$ in 2015 (Figure 1). The cumulative rainfall increased progressively from June to September, and tapered off in October and November, with most of the rain falling in July to September. No record was kept after November, as there was little rain in the dry season.

Maize grain yield from the cropping systems were indistinguishable in the first crop year (2014), but were differentiated by the second crop year (2015) (Table 2). 

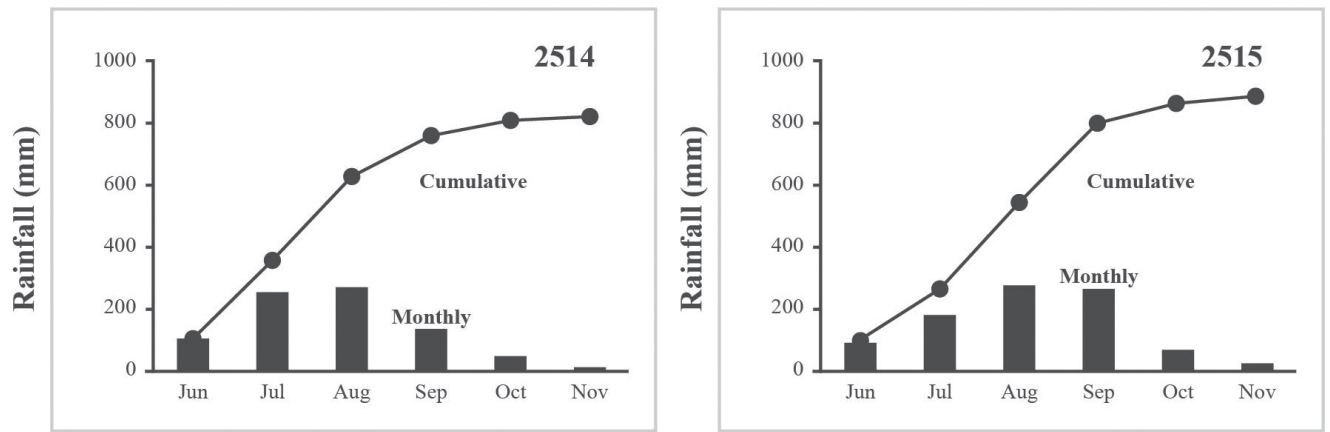

Figure 1. Monthly and cumulative rainfall from June to November during the two experimental years at $\mathrm{Na}$ Lou village, Santisuk district, Nan province, Thailand (Exp. 2).

Table 2. Grain yield of maize and lablab (14\% moisture) in three maize cropping systems at $\mathrm{Na}$ Lou village, Santisuk district, Nan, Thailand (Exp. 2)

\begin{tabular}{lcccc}
\hline \multirow{2}{*}{ Cropping system } & \multicolumn{3}{c}{ Maize } & \multicolumn{3}{c}{ Lablab } \\
\cline { 2 - 5 } & \multicolumn{5}{c}{ Grain yield (t/ha) } \\
\cline { 2 - 5 } & $\mathbf{2 0 1 4}$ & $\mathbf{2 0 1 5}$ & $\mathbf{2 0 1 4}$ & $\mathbf{2 0 1 5}$ \\
\hline Maize/lablab intercrop & 3.6 & $4.2 \mathrm{c}$ & $0.8 \pm 0.2^{1}$ & $0.2 \pm 0.03$ \\
Farmers' practice, with burning & 3.5 & $3.4 \mathrm{a}$ & 0 & 0 \\
Maize without burning & 3.5 & $3.9 \mathrm{~b}$ & 0 & 0 \\
\hline Significant difference $^{2}$ & $\mathrm{NS}(P<0.05)$ & $P<0.01$ \\
\hline
\end{tabular}

Note: ${ }^{1} \pm$ Standard deviation $(\mathrm{n}=3)$;

${ }^{2} \mathrm{By}$ analysis of variance, significant difference by $\mathrm{LSD}_{0.05}$ within same column indicated by different letters.

In the first crop year (2014), the maize yield in the three cropping systems were in the same range at 3.5-3.6 t/ha, but by the second crop year (2015), the maize yield was lowest at $3.4 \mathrm{t} / \mathrm{ha}$ in the farmers' practice of maize monocrop with residue burning, $15 \%$ higher in the maize monocrop without burning, and $24 \%$ higher in the maize/lablab intercrop without burning. Lablab grain yield was $0.8 \mathrm{t} / \mathrm{ha}$ in the first year (2014) and $0.2 \mathrm{t} / \mathrm{ha}$ in the second year (2015). Active nitrogen fixation in lablab was indicated by well nodulated roots. Crop residue differed little in maize monoculture with or without burning or between the first and second year, averaging $3.7 \mathrm{t} / \mathrm{ha}$; the maize/lablab residue was significantly higher with $6.4 \mathrm{t} / \mathrm{ha} / \mathrm{year}$, $2.5 \mathrm{t} /$ ha of which was the nitrogen-rich lablab residue (Table 3 ). 
Table 3. Dry weight of maize and lablab residue in three maize cropping systems at Na Lou village, Santisuk district, Nan, Thailand (Exp. 2).

\begin{tabular}{lcccccc}
\hline \multirow{2}{*}{ Cropping system } & \multicolumn{2}{c}{ Maize } & \multicolumn{2}{c}{ Lablab } & \multicolumn{2}{c}{ Total } \\
\cline { 2 - 7 } & \multicolumn{7}{c}{ Residue dry weight (t/ha) } \\
\cline { 2 - 7 } & $\mathbf{2 0 1 4}$ & $\mathbf{2 0 1 5}$ & $\mathbf{2 0 1 4}$ & $\mathbf{2 0 1 5}$ & $\mathbf{2 0 1 4}$ & $\mathbf{2 0 1 5}$ \\
\hline Maize/lablab intercrop & 3.8 & 4.0 & $2.5 \pm 0.2^{1}$ & $2.5 \pm 0.3$ & $6.3 \mathrm{~b}$ & $6.5 \mathrm{~b}$ \\
Farmer's practice, with burning & 3.6 & 3.6 & 0.0 & 0.0 & $3.6 \mathrm{a}$ & $3.6 \mathrm{a}$ \\
Maize without burning $^{\text {Significant difference }}{ }^{2}$ & 3.7 & 4.0 & 0.0 & 0.0 & $3.7 \mathrm{a}$ & $4.0 \mathrm{a}$ \\
\hline
\end{tabular}

Note: ${ }^{1} \pm$ standard deviation $(\mathrm{n}=3)$;

${ }^{2} \mathrm{By}$ analysis of variance, significant difference by $\mathrm{LSD}_{0.05}$ within same column indicated by different letters.

The effect of not burning the crop residue in reducing soil and nitrogen losses by erosion was significant in both years of the experiment, but the additional effect of intercropping became evident only in the second year (2015) (Table 4). In the first year (2014), a similar amount of soil (33-34 t/ha) was lost by erosion under either system without burning - the maize monocrop or maize/lablab intercrop, representing close to a $60 \%$ reduction from the $77.5 \mathrm{t} /$ ha lost under the farmers' practice of burning last season's residue. In the second year (2015), 52.5 t/ha of soil was lost under the farmer's practice with residue burning; without burning, the loss was reduced by almost $90 \%$ with the maize/lablab intercrop and $60 \%$ in the maize monocrop. Nitrogen loss associated with erosion under the different cropping systems followed the same pattern as the soil loss. In the first year (2014), a similar amount of nitrogen (57-58 kg N/ha) was lost by erosion under maize without burning, whether the monocrop or maize/lablab intercrop, representing close to a $70 \%$ reduction from the $183.1 \mathrm{~kg} \mathrm{~N} / \mathrm{ha}$ lost under the farmers' practice with residue burning. In the second year (2015), the $113.4 \mathrm{~kg} \mathrm{~N} / \mathrm{ha}$ that was lost under the farmers' practice was reduced by $40 \%$ in the maize monocrop without burning, and by almost $90 \%$ under the maize/lablab intercrop without burning.

Table 4. Soil and nitrogen loss due to erosion in maize cropping systems at $\mathrm{Na}$ Lou village, Santisuk district, Nan, Thailand.

\begin{tabular}{lccrc}
\hline \multirow{2}{*}{ Cropping system } & \multicolumn{2}{c}{ Soil loss (t/ha) } & \multicolumn{2}{c}{ Nitrogen loss (kg N/ha) } \\
\cline { 2 - 5 } & $\mathbf{2 0 1 4}$ & $\mathbf{2 0 1 5}$ & $\mathbf{2 0 1 4}$ & $\mathbf{2 0 1 5}$ \\
\hline Maize/lablab intercrop & $33.8 \mathrm{a}$ & $7.5 \mathrm{a}$ & $56.6 \mathrm{a}$ & $13.0 \mathrm{a}$ \\
Farmer's practice, with burning & $77.5 \mathrm{~b}$ & $52.5 \mathrm{c}$ & $183.1 \mathrm{~b}$ & $113.4 \mathrm{c}$ \\
Maize without burning $^{1}$ & $33.1 \mathrm{a}$ & $20.6 \mathrm{~b}$ & $58.5 \mathrm{a}$ & $41.2 \mathrm{~b}$ \\
\hline Significant difference $^{1}$ & $P<0.01$ & $P<0.01$ & $P<0.01$ & $P<0.01$ \\
\hline
\end{tabular}

Note: ${ }^{1}$ By analysis of variance, significant difference by $\operatorname{LSD}_{0.05}$ within same column indicated by different letters. 


\section{DISCUSSION}

The maize/legume intercrops produced more grain yield and residue containing large amounts of nitrogen that was retained, compared with the farmer's practice of growing maize with residue burning. The performance of the intercrop, however, varied with the legumes and their growth habit, with lablab having the largest positive effect on the three parameters measured: increasing maize yield, producing the most residue, and accumulating the most nitrogen. Lablab was followed by rice bean, with cowpea and mung bean having equally small effects. Lablab, with its trailing and twining growth habit (Murphy and Colucci, 1999), continued to grow and accumulate biomass for five months after the maize was harvested, compared to three more months for rice bean, two for cowpea, and one for mung bean. Preservation of crop residue, a key practice in conservation agriculture, is known to positively affect soil fertility (Fowler and Rockström, 2001; Hobbs, 2007). The cover provided by the maize/legume intercrops, both live during the growing season and as dead mulch, physically protected the soil surface against the elements, while biological activities that improve soil fertility were stimulated by the input of nitrogen-rich organic residue. A separate study on the impact of maize/legume intercrops on increasing soil biological diversity is reported elsewhere (Punyalue et al., 2018).

Flowering habit in plants has been classified into (a) determinate, in which the main growth axis ends in a flower, and (b) indeterminate, in which there is no terminal flower (Coen and Nugent, 1994). For the grain legumes, the indeterminate growth habit allows the plant to continue to grow new shoots and leaves after flowering, in contrast to the determinate type that stops growing vegetatively after flowering. Other researchers have also demonstrated the ability of lablab and rice bean in the highlands to accumulate large amounts of biomass and nitrogen (Chaiwong et al., 2012). However, their aggressive growth can be detrimental to the companion crop in intercropping, with lablab depressing maize grain yield in intercropping when sown at the same time (Devkota and Rerkasem, 2000). The harmful effect of legumes on maize yield was avoided in the present study by delaying sowing the legume until one month before the maize harvest. This practice of relay planting, i.e., sowing one crop into a standing crop of another, is known practice among some highland farmers in northern Thailand (Ongprasert and Prinz, 2004).

The higher maize grain yield from the intercrops than from the farmers' practice over the three years of Exp. 1 indicated a long-term effect of maize/legume intercrop; this suggested the potential of the maize/legumes intercrop in contributing to the sustainability of highland maize production in the long run. Crop legumes that are well nodulated with appropriate nitrogen-fixing bacteria are able to acquire nitrogen efficiently and economically from the atmosphere (Peoples and Craswell, 1992; Peoples et al., 2009). Intercrop legumes have been shown to be stimulated to become more dependent on biological fixation of $\mathrm{N}_{2}$ from the atmosphere by depletion of soil nitrogen by the cereal growing with them (Rerkasem et al., 1988; Jensen, 1996). The higher maize yield was also indicative of improved soil fertility under the maize/legume intercrops, with the acquisition of more nitrogen as well as the physical fertility from the input of nitrogen-rich organic matter (Fujita et al., 1992), in contrast to the loss of crop residue by burning in the farmers' practice. The need to clear the soil surface by burning, which is essential with the much smaller volume of residue from maize alone, was eliminated by the mulching effect of the intercrop residue. 
This study has demonstrated how soil and nitrogen loss by erosion in highland maize production in northern Thailand can be effectively reduced by intercropping the maize with lablab. The rainfall pattern differed only slightly in the two years of Exp. 2; results from the second year are here considered the cumulative treatment effects over time. Comparison with no-burn maize as well as the farmer's practice of growing maize after residue burning allows the effects of intercropping to be differentiated into (a) the elimination of burning and (b) the beneficial effects of adding legume to the cropping system. Not burning had an immediate effect in reducing soil and nitrogen loss by $60 \%$ in the first year (2014), and approximately the same again in the second year (2015), and a cumulative effect in raising the maize yield over the slash-and-burn maize by $15 \%$ in the second year (2015). With little difference in the residue dry weight in residue burning maize and no-burn maize in the two years of the experiment, the no-burn effects were achieved with the retention of some 3-4 t/ha biomass, along with the nitrogen and other volatile nutrients it contained, but were lost in the fire in the slash-and-burn maize. The additional benefits of introducing an intercrop legume into the system, with higher maize yield and greater reduction in soil and nitrogen losses by erosion in the maize/lablab intercropping than no-burn maize, were not realized until the second year (2015). Over the two seasons of the experiment, $12.8 \mathrm{t} / \mathrm{ha}$ of residue was added by maize/ lablab, containing almost $200 \mathrm{~kg} \mathrm{~N} / \mathrm{ha}$, assuming the residue nitrogen content at $1.51 \%$ from Exp. 1. The higher maize grain yield in maize/lablab in the second year (2015) was thus indicative of the responsiveness of the hybrid maize to the additional nitrogen made available by the legume, over and above the moderate rate applied as fertilizer.

In conclusion, this study has shown how intercropping maize with legumes in the highlands of northern Thailand increased maize grain yield over time and reduced soil erosion, all while eliminating the need to burn the crop residue with its associated detrimental haze effects. The additional harvest of legume grain may also provide farmers with an immediate economic incentive. However, where and when the legume grain yield is too low to offset the management cost of intercropping, farmers' adoption of maize/legume intercrops may need to be considered a provision of ecological services that need to be paid for by society at large. An integrated program in which strict enforcement against field burning, already in operation in the lowlands, is combined with provision of material support and technical advice may enable the practice to be adopted more widely and sustainably.

\section{ACKNOWLEDGEMENTS}

The authors wish to thank the farmers in the study village for their kind cooperation in the research. Support for the research from the Royal Project and National Research University Programme of the Commission on Higher Education of Thailand are gratefully acknowledged. 


\section{REFERENCES}

Beets, W.C. 1982. Multiple Cropping and Tropical Farming Systems. Westview Press, Boulder, Colorado, USA.

Boundeth, S., Nanseki, T., and Takeuchi, S. 2012. Analysis on technical efficiency of maize farmers in the northern province of Laos. African Journal of Agricultural Research. 7: 6579-6587. https://doi.org/10.5897/AJAR12.1814

Brooker, R.W., Bennett, A.E., Cong, W.F., Daniell, T.J., George, T.S., Hallett, P.D., Hawes, C., Iannetta, P.P.M., Jones, H.G., Karley, H.G., et al. 2015. Improving intercropping: a synthesis of research in agronomy, plant physiology and ecology. New Phytologist. 206: 107-17. https://doi.org/10.1111/nph.13132

Chaiwong, U. 2013. Green manures for highland paddy improvement. PhD Thesis (Agronomy), Graduate School, Chiang Mai University, Thailand.

Chaiwong, U., Yimyam, N., Rerkasem, K., and Rerkasem, B. 2012. Green manures for highland paddy in a mountainous area. Chiang Mai University Journal of Natural Science. 11: 103-107.

Coen, E.S., and Nugent, J.M. 1994. Evolution of flowers and inflorescences. Development. Suppl: 107-116

Devkota, N.R., and Rerkasem, B. 2000. Effects of cutting on the nitrogen economy and dry matter yield of lablab grown under monoculture and intercropped with maize in Northern Thailand. Experimental Agriculture. 36: 459-468. https://doi.org/10.1017/ S0014479700001034

Fowler, R., and Rockström, J. 2001. Conservation tillage for sustainable agriculture-an agrarian evolution gathers momentum in Africa. Soil and Tillage Research. 61: 93107. https://doi.org/10.1016/S0167-1987(01)00181-7

Francis, C.A. 1986. Distribution and importance of multiple cropping. In: Francis, C.A. (editor) Multiple Cropping Systems, MacMillan Publishing, New York, USA.

Fujita, K., Ofosu-Budu, K.G., and Ogata, S. 1992. Biological nitrogen fixation in mixed legume-cereal cropping systems. Plant and Soil. 141: 155-175. https://doi.org/10.1007/ BF00011315

Hill, R.D., and Peart, M.R. 1998. Land use, runoff, erosion and their control: a review for southern China. Hydrological Processes. 12: 2029-2042.

Hobbs, P.R. 2007. Conservation agriculture: what is it and why is it important for future sustainable food production? Journal of Agricultural Science. 145: 127-137.

Hurni, H. 1982. Soil erosion in Huai Thung Choa, Northern Thailand concerns and constraints. Mountain Research and Development. 2: 141-156. https://doi.org/10.2307/3672960

Jensen, E.S. 1996. Grain yield, symbiotic $\mathrm{N}_{2}$ fixation and interspecific competition for inorganic N in pea-barley intercrops. Plant and Soil. 182:29-37. https://doi.org/10.1007/ BF00010992

Kitchaicharoen, J., Suebpongsang, P., Sangchyoswat, C., and Promburom, P. 2015. Situational analysis in support of the development of integrated agricultural systems in the Upland Areas of Nan Province, Thailand. A Technical Report of the CGIAR Research program, humidtropics. https://doi.org/10.13140/RG.2.2.23008.89600

Murphy, A.M., and Colucci, P.E. 1999. A tropical forage solution to poor quality ruminant diets: A review of Lablab purpureus. Livestock Research for Rural Development. 11(2). Retrieved from http://www.cipav.org.co/lrrd/lrrd11/2/colu.htm 
Okigbo, B.N., and Greenland, D.J. 1976. Intercropping systems in tropical Africa. In: Papandick R.I., Sanchez P.A., and Tripplet G.B. (eds.), Multiple Cropping. American Society of Agronomy, Madison, Wisconsin. p. 63-101.

Ofori, F., and Stern, W.R. 1987. Cereal-legume intercropping systems. Advances in Agronomy. 41: 41-90. https://doi.org/10.1016/S0065-2113(08)60802-0

Ongprasert, S., and Prinz, K. 2004. Intensification of shifting cultivation by the use of viny legumes in Northern Thailand. Southeast Asian Studies. 41: 538-549. https://doi. org/10.20495/tak.41.4_538

Peoples, M.B., Brockwell, J., Herridge, D.F., Rochester, I.J., Alves, B.J.R., Urquiaga, S., Boddey, R.M., Dakora, F.D., Bhattarai, S., Maskey, S.L., et al. 2009. The contributions of nitrogen-fixing crop legumes to the productivity of agricultural systems. Symbiosis. 48: 1-17. https://doi.org/10.1007/BF03179980

Peoples, M.B., and Craswell, E.T. 1992. Biological nitrogen fixation: Investments, expectations and actual contributions to agriculture. Plant and Soil. 141: 13-40. https:// doi.org/10.1007/BF00011308

Pollution Control Department. 2012. Thailand's Air Quality and Situation Reports. Retrieved from http://air4thai.pcd.go.th/web/index.php

Punyalue, A., Jamjod, S., and Rerkasem, B. 2018. Intercropping maize with legumes for sustainable highland maize production. Mountain Research and Development. 38: In press

Rerkasem, B., and Rerkasem, K. 1987. Utilization of indigenous genetic resources by farmers in northern Thailand. In: Soemarwoto O., and Rambo A.T. (eds.), Impact of Development on Human Activity Systems in Southeast Asia, Proceedings of the $1^{\text {st }}$ SUAN/EAPI Regional Research Symposium, Institute of Ecology, the East West Center, Honolulu, Hawaii, USA and Padjadjaran University, Indonesia. p. 149-165.

Rerkasem, B., Rerkasem, K., Peoples, M.B., Herridge, D.F., and Bergersen, F.J. 1988. Measurement of $\mathrm{N}_{2}$ fixation in maize (Zea mays L.) - rice bean (Vigna umbellata [Thunb.] Ohwi and Ohashi) intercrops. Plant and Soil. 108: 125-135. https://doi. org/10.1007/BF02370107

Rerkasem, K., and Rerkasem, B. 1988. Yields and nitrogen nutrition of intercropped maize and ricebean (Vigna umbellata [Thunb.] Ohwi and Ohashi). Plant and Soil. 108: 151162. https://doi.org/10.1007/BF02370110

Wilson, C.G., Kuhnle, R.A., Bosch, D.D., Steiner, J.L., Starks, P.J., Tomer, M.D., Wilson, G.V. 2008. Quantifying relative contributions from sediment sources in conservation effects assessment project watersheds. Journal of Soil and Water Conservation. 63: 523-532. https://doi.org/10.2489/jswc.63.6.523

Woods, K. 2015. CP maize contract farming in Shan State, Myanmar: A regional case of a place-based corporate agro-feed system. Paper presented at Mekong Land Research Forum, RCSD, Chiang Mai University, 5-6 June 2015. Retrieved from http://www. iss.nl/fileadmin/ASSETS/iss/Research_and_projects/Research_networks/LDPI/ CMCP_35-_Woods.pdf

Yimyam, N. 2006. Fallow regeneration and upland rice yield variation in a system of shifting cultivation with PADA (Macaranga denticulata (BL.) Muell.Arg) as the fallow enriching species in Northern Thailand. PhD Thesis (Agronomy), Graduate School, Chiang Mai University, Thailand. 